\title{
Montbéliarde-sired crossbreds compared with pure Holsteins for dry matter intake, production, and body traits during the first 150 days of first lactation
}

\author{
A. R. Hazel, ${ }^{1}$ B. J. Heins, A. J. Seykora, and L. B. Hansen \\ Department of Animal Science, University of Minnesota, St. Paul 55108
}

\begin{abstract}
Montbéliarde (MO)-sired crossbred cows $(\mathrm{n}=57)$ were compared with pure Holstein $(\mathrm{HO})$ cows $(\mathrm{n}=40)$ for dry matter intake (DMI), production, hip height, body condition score (BCS), and body weight (BW) during the first $150 \mathrm{~d}$ of first lactation. Also, production for $305 \mathrm{~d}$ was compared for first lactation. The MOsired crossbred cows were composed of $\mathrm{MO} \times \mathrm{HO}$ cows $(\mathrm{n}=33)$ and $\mathrm{MO} \times$ Jersey $/ \mathrm{HO}$ cows $(\mathrm{n}=24)$. Cows were individually fed a total mixed ration twice daily. The DMI was measured for the first $150 \mathrm{~d}$ of lactation, except from d 1 to 3 postpartum to permit cows to acclimate to stalls in a confinement barn. Hip height was measured once between 20 and $172 \mathrm{~d}$ postpartum, and $\mathrm{BCS}$ and $\mathrm{BW}$ were recorded every other week. The MOsired crossbred cows did not differ from the pure $\mathrm{HO}$ cows for 150-d DMI, 150-d fat plus protein production, or for 305-d fat plus protein production. Hip height was similar for $\mathrm{MO} \times \mathrm{HO}$ and pure $\mathrm{HO}$ cows, but $\mathrm{MO} \times$ Jersey/HO cows had shorter hip height than the pure HO cows. Despite the lack of difference for DMI, the MO-sired crossbred cows had significantly greater BCS (3.30 vs. 2.74 ) and $\mathrm{BW}$ (551 vs. $528 \mathrm{~kg}$ ) than the pure HO cows. The MO-sired crossbred cows (122 d) had fewer days open than the pure HO cows $(150 \mathrm{~d})$. The higher BCS of the MO-sired crossbred cows, especially during early lactation, may have provided an advantage for fertility. Differences for DMI between breed groups were not studied for the latter half of first lactation or for multiparous cows.
\end{abstract}

Key words: crossbreeding, Montbéliarde, dry matter intake

\section{INTRODUCTION}

Some dairy producers have embraced crossbreeding to enhance the profitability of dairying by improving fertility, decreasing health costs, and enhancing the survival of cows (McAllister, 2002; Weigel and Barlass,

Received April 27, 2012.

Accepted November 11, 2012.

${ }^{1}$ Corresponding author: haze0025@umn.edu
2003). Globally, the beef, pig, and poultry industries have used heterosis for commercial production for decades to capitalize on the documented gains for fertility, health, and profitability; however, heterosis can also be expressed as improved feed efficiency of animals (Rolfe et al., 2011). An important component of profitability of dairying is feed cost (Shalloo et al., 2004), and feed efficiency has a tremendous impact on profit from dairy cows.

Jersey $\times$ Holstein $(\mathbf{J H})$ crossbred cows were more feed efficient than pure Holstein (HO) cows for Schwager-Suter et al. (2001), and they hypothesized that heterosis may be responsible for lower energy requirements for one or more energy partitions of milk production, maintenance, and body tissue mobilization and deposition. In an Irish study, JH crossbred cows $(16.2 \mathrm{~kg})$ and pure HO cows $(16.9 \mathrm{~kg})$ had similar DMI; however, the $\mathrm{JH}$ crossbred cows had greater feed efficiency, which was measured as net energy intake over production of milk solids (Prendiville et al., 2009).

Olson et al. (2010) reported that JH reciprocal crossbred cows produced milk that contained the same amount of $\mathrm{NE}_{\mathrm{L}}$ as pure $\mathrm{HO}$ cows during first lactation; however, the $\mathrm{JH}$ crossbred cows sired by $\mathrm{HO}$ bulls consumed less energy in feed than did pure HO cows. However, Heins et al. (2008) reported that JH crossbred cows and pure HO cows had similar DMI and production during the first $150 \mathrm{~d}$ of first lactation and, because the JH crossbred cows were smaller for frame size, the authors concluded that JH crossbred cows used DMI beyond their needs for production and maintenance to achieve greater BCS. Also, the feed efficiency of Ayrshire $\times \mathrm{HO}$, Brown Swiss $\times \mathrm{HO}$, and 3-breed crossbred cows (Ayrshire, Brown Swiss, and HO) was similar to that of pure HO cows for McDowell (1982).

Little research has been conducted to compare crossbred cows sired by Montbéliarde (MO) bulls with pure HO cows, because MO semen has been marketed globally only during the past decade. Furthermore, actual DMI for individual cows is costly to collect and, therefore, direct measures of DMI have not been previously reported for MO-sired crossbred cows compared with pure HO contemporaries. 
A long-term Irish study was initiated to compare Irish pure HO, imported French pure MO, and their resulting $\mathrm{MO} \times \mathrm{HO}$ progeny in a grass-based production system. Dillon et al. (2003) observed differences in estimated DMI, which was calculated from fecal alkane concentrations, for pure $\mathrm{MO}$ and pure $\mathrm{HO}$ cows in 3 periods during lactation. The pure $\mathrm{MO}$ cows had lower daily DMI (16.4 vs. $18.4 \mathrm{~kg}$ ) but also proportionally lower SCM (4,769 vs. $5,560 \mathrm{~kg})$ than pure HO cows. Therefore, Dillon et al. (2003) reported equivalent feed efficiency for the 2 pure breeds. A follow-up study reported that the imported French pure MO cows were more profitable than the Irish pure $\mathrm{HO}$ under several milk quota scenarios (Evans et al., 2004). Subsequently, pure $\mathrm{MO}, \mathrm{MO} \times \mathrm{HO}$, and pure $\mathrm{HO}$ cows, which were daughters of cows from Dillon et al. (2003) and Evans et al. (2004), were evaluated over several lactations in a 5-yr study by Walsh et al. (2008), who reported that $\mathrm{SCM}$ was similar for $\mathrm{MO} \times \mathrm{HO}$ and pure $\mathrm{HO}$ cows but lower for pure MO cows. Furthermore, BCS was highest for pure MO cows (3.15), intermediate for MO $\times$ HO cows (3.00), and lowest for pure HO cows (2.77), but BW was similar for the 3 breed groups (Walsh et al., 2008). Notably, the MO $\times$ HO cows were 2.4 times more likely to be pregnant at the end of the breeding season compared with pure $\mathrm{HO}$ cows (Walsh et al., 2008). Buckley et al. (2007) also calculated DMI for cows from alkane concentrations for 2 fecal collection periods during early first through fourth lactations of pure $\mathrm{MO}, \mathrm{MO} \times \mathrm{HO}$, and pure $\mathrm{HO}$ cows. The MO $\times \mathrm{HO}$ and pure $\mathrm{HO}$ cows were similar for both DMI and milk solids production; therefore, feed efficiency was likewise similar. However, pure MO cows had less DMI, lower milk solids production, and reduced feed efficiency than pure HO cows (Buckley et al., 2007).

An Israeli study (Aharoni et al., 2006) compared the heart rates and oxygen consumption of 7 multiparous $\mathrm{MO} \times \mathrm{HO}$ crossbred cows and 7 multiparous pure $\mathrm{HO}$ cows during two 10-d periods. Their equations predicted that $\mathrm{MO} \times \mathrm{HO}$ cows had lower ME intake than pure $\mathrm{HO}$ cows; however, $\mathrm{MO} \times \mathrm{HO}$ cows also had less gross efficiency, because $\mathrm{MO} \times \mathrm{HO}$ cows were penalized for having greater BCS and BW.

A study of 6 commercial dairies in California reported that $\mathrm{MO} \times \mathrm{HO}$ cows had somewhat lower fat plus protein production, but superior fertility, during 305-d first lactations compared with pure $\mathrm{HO}$ cows (Heins and Hansen, 2012). A subsequent economic analysis indicated that $\mathrm{MO} \times \mathrm{HO}$ cows had $5.3 \%$ greater lifetime profit per day than pure $\mathrm{HO}$ cows (Heins et al., 2012) when DMI was predicted from FCM equivalently across breed groups. Costs of health treatments were not available for Heins et al. (2012), and inclusion of health costs might have increased the profitability of $\mathrm{MO} \times \mathrm{HO}$ cows versus pure $\mathrm{HO}$ cows.

For economic merit, VanRaden and Sanders (2003) reported that both Brown Swiss $\times \mathrm{HO}$ cows and $\mathrm{JH}$ crossbred cows were superior to pure HO cows for the Net Merit index in the United States. A review of crossbreeding by Sørensen et al. (2008) concluded that heterosis of at least 10\% can be expected for total economic merit of both $\mathrm{F}_{1}$ and 3-breed crossbred cows.

The objectives of this study were to evaluate phenotypic differences for traits related to energy use for MO-sired crossbred and pure HO cows housed in a confinement system during the first $150 \mathrm{~d}$ of first lactation. Breed groups were compared for DMI and production during the first $150 \mathrm{~d}$ of first lactation; however, 305-d production was also compared to provide a broader assessment of total production performance during first lactation. Additionally, body traits were compared during the first $150 \mathrm{~d}$ of first lactation. A subsequent study using a larger number of MO-sired crossbred and pure $\mathrm{HO}$ cows in 2 institutional herds will evaluate production, fertility, and survival, but not DMI, because of the high cost of data collection.

\section{MATERIALS AND METHODS}

\section{Experimental Design}

Cows in this study calved during 3 fall seasons: October to December 2005, October 2006 to January 2007, and October to December 2007, and cows were sired by MO or HO AI bulls selected on high rank for the ISU total merit index (O. S. Montbéliarde, 2012) in France for MO bulls or the Net Merit index (Cole et al., 2009b) in the United States for HO bulls. Three bulls were selected annually for each breed, and the MO bulls were among the top 10 proven AI bulls in France and the HO bulls were among the highest 1 percentile in the United States.

The 57 MO-sired crossbred cows were sired by $9 \mathrm{MO}$ AI bulls, and the 40 pure $\mathrm{HO}$ cows were sired by $16 \mathrm{HO}$ AI bulls (Table 1). Dams of cows were either pure HO or JH crossbred cows, and dams of cows were sired by high-ranking AI bulls for the Net Merit index in the United States for both the Jersey and HO breeds at the time of sire selection. Cows in this study calved from 22 to $34 \mathrm{mo}$ of age and were assigned to 3 classes of age at first calving: 22 to 23 mo (26 MO-sired crossbred and 17 pure HO cows), 24 to 26 mo (27 MO-sired crossbred and 16 pure HO cows), and 29 to 34 mo (4 MO-sired crossbred and 7 pure HO cows). The mean age of first calving was $24.3 \pm 0.3 \mathrm{mo}$ for the MO-sired crossbred cows and $24.9 \pm 0.5$ mo for the pure HO cows. 
Table 1. Number of cows by year of fall calving by breed group

\begin{tabular}{lccc}
\hline Year & $\begin{array}{c}\text { Pure } \\
\text { Holstein }\end{array}$ & $\begin{array}{c}\text { Montbéliarde } \\
\times \text { Holstein }\end{array}$ & $\begin{array}{c}\text { Montbéliarde } \\
\times \text { Jersey/Holstein }\end{array}$ \\
\hline 2005 & 11 & 14 & 1 \\
2006 & 13 & 12 & 11 \\
2007 & 16 & 7 & 12 \\
Total & 40 & 33 & 24 \\
\hline
\end{tabular}

Three cows were removed from the study within the first $90 \mathrm{~d}$ of first lactation. In the first year, 1 pure HO cow died from gangrene mastitis at $72 \mathrm{~d}$ postpartum. In the second year, 1 pure HO died from Escherichia coli mastitis at $90 \mathrm{~d}$ postpartum. In the third year, $1 \mathrm{MO}$ $\times \mathrm{JH}$ crossbred cow was culled for gangrene mastitis at 56 d postpartum.

\section{DMI and Production}

Cows were fed an ad libitum TMR diet consisting of $55 \%$ forage and $45 \%$ concentrate, and diet was adjusted monthly to account for changes in DM of ingredients. Diets were composed of corn silage, chopped alfalfa hay, soybean meal, ground corn, concentrate supplements, vitamins, and minerals. Cows were fed twice daily with a Calan Data Ranger (American Calan, Northwood, $\mathrm{NH}$ ), and feed refusals were collected once daily to determine daily DMI $(\mathrm{kg})$ for each cow. Daily DMI was collected from d 4 to 150 postpartum. The DMI was not recorded for the first $3 \mathrm{~d}$ postpartum because cows were allowed to acclimate to tie stalls until d 3 of lactation. To analyze total 150-d DMI, the actual daily DMI observations were summed for each cow. Only 19 of the 14,259 daily observations for DMI were missing, and they were for 4 cows between 4 and $13 \mathrm{~d}$ postpartum. For 3 cows, data were missing because of computer recording errors, and 1 cow had difficulty acclimating to the tie stall. The 19 missing daily observations were estimated by extrapolation to determine the 150-d DMI for these 4 cows.

Independent variables for the statistical analysis of 150-d DMI included year of calving, age class at first calving, breed of sire, and $\mathrm{MO} \times \mathrm{HO}$ versus $\mathrm{MO} \times \mathrm{JH}$ nested within MO breed of sire. The GLM procedure of SAS (SAS Institute, 2008) was used to conduct the ANOVA and obtain solutions.

Test-day observations for twice-daily milking from DHI were used as inputs to estimate production. Standard edits used by the US Department of Agriculture for routine genetic evaluations were applied to all testday observations. Each test-day was required to have an observation for milk, fat, and protein production. Fat percentage was required to be at least $1.0 \%$, but no more than $9.9 \%$, and protein percentage was required to be at least $1.0 \%$, but no more than $6.0 \%$. Test-day milk weights were required to be $\geq 4.54 \mathrm{~kg}$. A first testday was required by 90 DIM, and individual test-days from first lactation were used to predict 150-d milk $(\mathrm{kg})$, fat $(\mathrm{kg})$, and protein $(\mathrm{kg})$ production and SCS with best prediction (Cole et al., 2009a). The 150-d fat plus protein $(\mathrm{kg})$ was the sum of the 150-d production records of fat and protein. The 150-d SCS for each cow was the mean of predicted daily SCS.

The 305-d production was also estimated with best prediction using test-days beyond 150 DIM. Lactations shorter than 305 d were projected to 305 d. The $305-\mathrm{d}$ fat plus protein $(\mathrm{kg})$ was the sum of the $305-\mathrm{d}$ production records of fat and protein for each cow, and the 305-d SCS was the mean of predicted daily SCS.

Independent variables for the statistical analysis of both 150-d and 305-d milk, fat, and protein production, fat plus protein production, and SCS were year of calving, age class at first calving, breed of sire, and $\mathrm{MO} \times$ $\mathrm{HO}$ versus $\mathrm{MO} \times \mathrm{JH}$ nested within $\mathrm{MO}$ breed of sire. The GLM procedure of SAS was used to conduct the ANOVA and obtain solutions for production and SCS.

\section{Body Traits}

Hip height $(\mathbf{H H})$ was objectively measured from the ground to the sacrum once between 20 and 172 DIM while cows were in their tie stalls, and measurements were recorded in increments of $0.5 \mathrm{~cm}$. Independent variables for the statistical analysis of $\mathrm{HH}$ were the fixed effects of year of calving, age class at first calving, breed of sire, and $\mathrm{MO} \times \mathrm{HO}$ versus $\mathrm{MO} \times \mathrm{JH}$ nested within $\mathrm{MO}$ breed of sire. A preliminary model included a covariable for DIM at the time of measurement, but DIM was not significant $(P=0.85)$ and was removed from the model. The GLM procedure of SAS was used to conduct the ANOVA and obtain solutions.

Body condition score and BW were recorded during the p.m. milking every other week during the first $150 \mathrm{~d}$ postpartum; therefore, most cows had 10 observations for BW and BCS at 14-d intervals (e.g., 1 to $15 \mathrm{~d}, 16$ to $30 \mathrm{~d}, 31$ to $45 \mathrm{~d}$ ). The BCS was measured by the same person throughout the study on a 1 to 5 scale (1 $=$ thin and $5=$ obese) in increments of 0.25 (Ferguson et al., 1994), and BW was recorded for each cow using a digital scale as cows exited the milking parlor.

Statistical analysis of BCS and BW had fixed effects of year of calving, age class at first calving, breed of sire, $\mathrm{MO} \times \mathrm{HO}$ versus $\mathrm{MO} \times \mathrm{JH}$ nested within $\mathrm{MO}$ breed of sire, and 14-d period nested within breed of sire. The MIXED procedure of SAS was used for analysis, and cow nested within breed of sire and within $\mathrm{MO} \times \mathrm{HO}$ versus $\mathrm{MO} \times \mathrm{JH}$ was defined as a random variable with repeated measures for 14 -d periods. The 
first order auto-regressive $[\mathrm{AR}(1)]$ covariance structure was used, because it resulted in the lowest Akaike's information criterion (Littell et al., 1998).

All phenotypic pairwise correlations of the 3 body traits were examined within each breed group, and the means of the repeated measures of BCS and BW of cows were analyzed. For each of the 3 body traits, adjustment factors for the fixed effects of year of calving and age class at first calving within breed groups were obtained using the least squares solutions from the GLM procedure of SAS, and the adjusted observations for each cow were used to calculate Pearson correlation coefficients. Statistical significance was declared when $P$-values were $<0.05$; however, tendencies toward statistical significance $(0.05<P<0.1)$ were also reported.

\section{RESULTS AND DISCUSSION}

\section{DMI and Production}

For total DMI, year of calving and age class at calving were the only independent variables that significantly explained variation. Cows calving in 2005 (3,109 kg) had significantly $(P<0.05)$ greater total DMI than cows calving in $2006(2,916 \mathrm{~kg})$ and $2007(2,831 \mathrm{~kg})$. Table 2 shows total DMI for cows calving from 22 to $23 \mathrm{mo}, 24$ to $26 \mathrm{mo}$, and 29 to $34 \mathrm{mo}$ of age, and the least squares means for DMI were significantly greater for cows calving at 29 to 34 mo of age than at younger ages.

Total DMI for the 150-d period was not different $(P$ $=0.17)$ for $\mathrm{MO} \times \mathrm{HO}(2,904 \mathrm{~kg}), \mathrm{MO} \times \mathrm{JH}(2,906 \mathrm{~kg})$, and pure HO (2,999 kg) cows (Table 3); therefore, we found no evidence to suggest that MO-sired crossbred cows had greater DMI than pure HO cows. Of course, because DMI was only collected for the first 150 DIM, conclusions cannot be made regarding DMI during the latter half of lactation and during subsequent lactations. Differences in nutrient requirements for cows may change after the first $150 \mathrm{~d}$ of first lactation because skeletal growth subsides for cows after first lactation and, additionally, fetal development requires a meaningful amount of nutrients during the final trimester of pregnancy (NRC, 2001).

For $150-d$ milk, fat, and protein production, only age class at calving significantly explained variation among the nonbreed effects in the stated model, and least squares means for production significantly increased with age at first calving (Table 2). For SCS, age at first calving was not significant $(P=0.69)$; however, cows calving in $2005(2.95)$ had significantly $(P<0.05)$ higher SCS than cows calving in 2006 (2.34) and 2007 (2.25).

Least squares means of 150-d production and SCS for breed groups are in Table 3 . The $\mathrm{MO} \times \mathrm{HO}$ and $\mathrm{MO}$ $\times \mathrm{JH}$ crossbred cows had significantly $(P<0.05)$ lower 150-d milk volume than the pure HO cows; however, production of fat plus protein did not differ significantly $(P=0.62)$ and was very similar for $\mathrm{MO} \times \mathrm{HO}(306 \mathrm{~kg})$, $\mathrm{MO} \times \mathrm{JH}(310 \mathrm{~kg})$, and pure HO $(311 \mathrm{~kg})$ cows (Table $3)$. Also, SCS was not significantly different $(P=0.42)$ for breed groups during the first 150-d of first lactation.

For lactational 305-d milk, fat, and protein production, only age class at calving significantly explained variation among the nonbreed effects in the model. Least squares means for 305-d production (Table 2) increased with age at first calving, but SCS was not different $(P=0.74)$ for age class at first calving. For breed groups, the 305-d milk volume tended $(P=0.07)$ to be lower for the $\mathrm{MO} \times \mathrm{HO}$ crossbreds and was sig-

Table 2. Least squares means and standard errors of means for DMI, production, and SCS for age class at first calving across breed groups

\begin{tabular}{|c|c|c|c|c|c|c|}
\hline \multirow[b]{2}{*}{ Trait } & \multicolumn{2}{|c|}{$\begin{array}{l}22 \text { to } 23 \mathrm{mo} \\
\quad(\mathrm{n}=43)\end{array}$} & \multicolumn{2}{|c|}{$\begin{array}{c}24 \text { to } 26 \mathrm{mo} \\
(\mathrm{n}=43)\end{array}$} & \multicolumn{2}{|c|}{$\begin{array}{l}29 \text { to } 34 \mathrm{mo} \\
(\mathrm{n}=11)\end{array}$} \\
\hline & Mean & SEM & Mean & SEM & Mean & SEM \\
\hline \multicolumn{7}{|l|}{$150 \mathrm{~d}$} \\
\hline DMI (kg) & $2,802^{\mathrm{a}}$ & 47.1 & $2,922^{\mathrm{a}}$ & 45.3 & $3,132^{\mathrm{b}}$ & 88.8 \\
\hline Milk (kg) & $4,339^{\mathrm{a}}$ & 61.1 & $4,660^{\mathrm{b}}$ & 58.8 & $4,991^{\mathrm{c}}$ & 115.2 \\
\hline Fat $(\mathrm{kg})$ & $154^{\mathrm{a}}$ & 2.5 & $165^{\mathrm{b}}$ & 2.4 & $184^{\mathrm{c}}$ & 4.7 \\
\hline Protein (kg) & $133^{\mathrm{a}}$ & 1.8 & $141^{\mathrm{b}}$ & 1.7 & $153^{\mathrm{c}}$ & 3.4 \\
\hline Fat plus protein $(\mathrm{kg})$ & $287^{\mathrm{a}}$ & 4.1 & $305^{\mathrm{b}}$ & 3.9 & $336^{\mathrm{c}}$ & 7.7 \\
\hline SCS & $2.5^{\mathrm{a}}$ & 0.2 & $2.4^{\mathrm{a}}$ & 0.2 & $2.7^{\mathrm{a}}$ & 0.3 \\
\hline \multicolumn{7}{|l|}{$305 \mathrm{~d}$} \\
\hline Milk (kg) & $8,453^{\mathrm{a}}$ & 110.9 & $8,972^{\mathrm{b}}$ & 106.8 & $9,605^{\mathrm{c}}$ & 209.2 \\
\hline Fat $(\mathrm{kg})$ & $303^{\mathrm{a}}$ & 4.5 & $319^{\mathrm{b}}$ & 4.3 & $353^{\mathrm{c}}$ & 8.5 \\
\hline Protein $(\mathrm{kg})$ & $266^{\mathrm{a}}$ & 3.5 & $278^{\mathrm{b}}$ & 3.3 & $301^{\mathrm{c}}$ & 6.5 \\
\hline Fat plus protein $(\mathrm{kg})$ & $569^{\mathrm{a}}$ & 7.5 & $597^{\mathrm{b}}$ & 7.2 & $654^{\mathrm{c}}$ & 14.2 \\
\hline SCS & $2.4^{\mathrm{a}}$ & 0.2 & $2.3^{\mathrm{a}}$ & 0.2 & $2.6^{\mathrm{a}}$ & 0.3 \\
\hline
\end{tabular}

${ }^{\mathrm{a}-\mathrm{c}}$ Means with different superscript letters within rows indicate $P<0.05$. 
Table 3. Least squares means and standard errors of means for DMI, production, and SCS for breed groups

\begin{tabular}{|c|c|c|c|c|c|c|}
\hline \multirow[b]{2}{*}{ Trait } & \multicolumn{2}{|c|}{$\begin{array}{l}\text { Pure Holstein } \\
\quad(\mathrm{n}=40)\end{array}$} & \multicolumn{2}{|c|}{$\begin{array}{c}\text { Montbéliarde } \times \text { Holstein } \\
(\mathrm{n}=33)\end{array}$} & \multicolumn{2}{|c|}{$\begin{array}{c}\text { Montbéliarde } \times \\
\text { Jersey/Holstein }(\mathrm{n}=24)\end{array}$} \\
\hline & Mean & SEM & Mean & SEM & Mean & SEM \\
\hline \multicolumn{7}{|l|}{$150 \mathrm{~d}$} \\
\hline DMI (kg) & 2,999 & 48.2 & 2,904 & 55.0 & 2,906 & 69.6 \\
\hline Milk (kg) & 4,764 & 62.6 & $4,573^{*}$ & 71.4 & $4,552^{*}$ & 90.3 \\
\hline Fat $(\mathrm{kg})$ & 168 & 2.6 & 166 & 2.9 & 168 & 3.7 \\
\hline Protein $(\mathrm{kg})$ & 143 & 1.8 & 140 & 2.1 & 142 & 2.6 \\
\hline Fat plus protein $(\mathrm{kg})$ & 311 & 4.2 & 306 & 4.8 & 310 & 6.1 \\
\hline SCS & 2.4 & 0.2 & 2.4 & 0.2 & 2.7 & 0.2 \\
\hline \multicolumn{7}{|l|}{$305 \mathrm{~d}$} \\
\hline Milk (kg) & 9,200 & 113.6 & $8,905 \dagger$ & 129.6 & $8,735^{*}$ & 164.0 \\
\hline Fat $(\mathrm{kg})$ & 326 & 4.6 & 324 & 5.3 & 324 & 6.7 \\
\hline Protein (kg) & 284 & 3.5 & 280 & 4.0 & 279 & 5.1 \\
\hline Fat plus protein (kg) & 610 & 7.7 & 604 & 8.8 & 603 & 11.1 \\
\hline SCS & 2.4 & 0.2 & 2.4 & 0.2 & 2.7 & 0.2 \\
\hline
\end{tabular}

$* P<0.05$ and $\dagger P<0.10$ for difference from pure Holstein cows.

nificantly $(P<0.05)$ lower for $\mathrm{MO} \times \mathrm{JH}$ crossbreds compared with pure HO cows. However, production of fat plus protein, again, did not differ $(P=0.97)$ and was essentially equivalent for $\mathrm{MO} \times \mathrm{HO}(604 \mathrm{~kg}), \mathrm{MO}$ $\times \mathrm{JH}(603 \mathrm{~kg})$, and pure HO $(610 \mathrm{~kg})$ cows for $305-\mathrm{d}$ lactations (Table 3). Also, SCS was not significantly different $(P=0.29)$ for the breed groups (Table 3 ). The results for fat plus protein production in this study differ somewhat from the results of Heins and Hansen (2012), who reported that $\mathrm{MO} \times \mathrm{HO}$ crossbred cows had $3 \%$ lower fat plus protein production than did pure $\mathrm{HO}$ cows during first lactation.

Fat plus protein production has the largest effect on the value of milk for approximately $93 \%$ of milk produced in the United States (US Department of Agriculture-Agricultural Marketing Service, 2012; US Department of Agriculture-National Agricultural Statistics Service, 2012). Therefore, the majority of dairy producers in the United States should not be alarmed by potentially lower milk volume of MO-sired crossbred cows compared with pure HO cows. The higher components in the milk of MO-sired crossbred cows may actually increase production efficiency, because the additional energy required by pure $\mathrm{HO}$ to synthesize greater milk volume is a loss of energy. Also, farming systems incur higher costs for equipment and electricity to cool and store additional fluid carrier (Cole et al., 2009b).

Measures of feed efficiency are often inherently problematic, and feed efficiency was not evaluated in this study. Most previous research has examined only DM or nutrients consumed versus energy in milk or solids produced without regard for changes in body composition or pregnancy status. A ratio trait of input (feed intake) divided by output (production) can be especially misleading, because analyzing the ratio of 2 traits often leads to spurious results that are highly correlated with the numerator or denominator. Emphasis during statistical analysis, especially ANOVA, is directed toward the numerator or denominator with the greatest variance (Sutherland, 1965). Additionally, Berry (2009) pointed out the disadvantages of including ratio traits in selection schemes because correlated traits are often undesirable, such as reduced appetite or other behavioral traits that influence DMI.

Residual feed intake (RFI) has become a popular method of gauging feed efficiency of dairy cattle during the past 5 yr (Berry, 2009), but RFI may not be appropriate for analyzing data that compare crossbred with pure HO cows. The RFI is calculated by subtracting actual DMI from expected DMI (NRC, 2001), and the expected DMI is defined as a function of BW, FCM, and week of lactation. By this definition, RFI does not consider the differences in BCS, proportion of adipose and muscular tissue, frame size, or heterosis for production or DMI. Furthermore, formulas used to predict DMI are based primarily on measurements from pure HO cows. Prendiville et al. (2009) argued that RFI poses problems for dairy cows, because cows mobilize energy reserves during early lactation but replenish these reserves later in lactation. The change in body composition during lactation complicates the calculation of profit from salvage value, because value of the carcass decreases during early lactation, but increases in value during later lactation.

Cows determined to be the most efficient by standard measures of feed efficiency may not be economically efficient if they have low DMI and low production (Prendiville et al., 2009), because these cows still incur direct and overhead costs at the same rate as higherproducing cows. Furthermore, low-producing cows have a higher risk of being culled (Pinedo et al., 2010), and 
these "poor doer" cows often have low BCS, which may be associated with impaired fertility, higher disease incidence, and lower salvage value. For these reasons, measures of feed efficiency that only consider units of energy intake and output do not necessarily identify the most profitable cows.

\section{Body Traits}

Year of first calving, age class at first calving, and breed group significantly $(P<0.01)$ explained variation for HH. For year of calving, cows had HH of 137.8, 142.9 , and $141.5 \mathrm{~cm}$ for 2005,2006 , and 2007, respectively. For age class at first calving, $\mathrm{HH}$ increased as expected (139.0 cm for 22 to $23 \mathrm{mo}, 140.8 \mathrm{~cm}$ for 24 to $26 \mathrm{mo}$, and $142.5 \mathrm{~cm}$ for 29 to $34 \mathrm{mo}$ ). The $\mathrm{MO} \times$ HO $(141.4 \mathrm{~cm})$ and pure HO $(141.8 \mathrm{~cm})$ cows did not differ $(P=0.58)$ for $\mathrm{HH}$; however, $\mathrm{MO} \times \mathrm{JH}$ cows had significantly $(P<0.01)$ shorter $\mathrm{HH}$ than pure $\mathrm{HO}$ cows (Table 4). Pure Jersey cows have smaller frame size than pure $\mathrm{HO}$ cows, and the one-fourth Jersey content of the $\mathrm{MO} \times \mathrm{JH}$ cows in this study is the likely explanation for the shorter HH. Heins et al. (2011) reported that $\mathrm{JH}$ crossbred cows had 8.8 to $9.4 \mathrm{~cm}$ shorter $\mathrm{HH}$ than pure HO cows during their first 3 lactations.

Among the fixed effects in the statistical model for BCS, only breed group and 14-d period nested within breed of sire significantly $(P<0.01)$ explained any variation. For breed groups, the MO-sired crossbred cows had significantly greater BCS than pure HO cows throughout the study, with least squares means of 3.32, 3.29 , and 2.74 for $\mathrm{MO} \times \mathrm{HO}, \mathrm{MO} \times \mathrm{JH}$, and pure $\mathrm{HO}$ cows, respectively (Table 4). Least squares means for BCS in each of the 14-d periods were different $(P<$ 0.01) for MO-sired crossbreds compared with pure $\mathrm{HO}$ cows, and differences for BCS between breed groups ranged from 0.47 to 0.64 and were greater for the first $100 \mathrm{~d}$ postpartum than for the subsequent $50 \mathrm{~d}$ postpartum.

The MO-sired crossbred and pure HO cows both mobilized body tissue during early lactation to meet the demands of production. Throughout the 150-d study period, the MO-sired crossbreds maintained greater BCS than the pure HO cows, and the greater BCS may explain the superior fertility (Dechow et al., 2001; Pryce et al., 2001) of the MO-sired crossbreds in this study and may also reduce occurrence of disease during early lactation (Hansen et al., 2002; Zwald et al., 2004). Similarly, a study comparing JH crossbred and pure HO cows in Australia (Auldist et al., 2007) concluded that JH crossbred cows had both greater BCS and superior fertility compared with pure $\mathrm{HO}$ cows.

The effects of age class at first calving, breed group, and 14-d period nested within breed of sire all explained variation for $\mathrm{BW}$. The $\mathrm{BW}$ increased as age class at first calving increased $(503,533$, and $581 \mathrm{~kg}$ for the 3 age classes, respectively), and all orthogonal contrasts for each of the 3 age classes were highly significant $(P$ $<0.01$ ). For breed groups (Table 4 ), the $\mathrm{MO} \times \mathrm{HO}$ crossbred cows had $(P<0.01)$ greater BW than pure HO cows across the first $150 \mathrm{~d}$ of first lactation (564 vs. $528 \mathrm{~kg}$ ). The results presented here differed from Walsh et al. (2008), who found that BW was similar for $\mathrm{MO} \times \mathrm{HO}(572 \mathrm{~kg})$, pure $\mathrm{HO}(570 \mathrm{~kg})$, and pure MO cows $(568 \mathrm{~kg})$ from first through fifth lactations. For the current study, $\mathrm{MO} \times \mathrm{JH}$ cows $(537 \mathrm{~kg})$ were similar to pure HO cows for BW (Table 4).

Least squares means for BW for each 14-d period by breed of sire are in Table 5. The MO-sired crossbred cows $(555 \mathrm{~kg})$ had greater BW immediately after calving compared with pure $\mathrm{HO}$ cows $(527 \mathrm{~kg})$. Daughters of MO versus HO sires decreased similarly for BW between periods 1 and 2, had similar nadir BW between periods 2 and 4 , and then BW rapidly increased starting in period 5 . The largest difference in BW was immediately after calving and the difference tended to decrease as lactation progressed past the 12th week of lactation. Furthermore, the MO-sired crossbred cows gained less BW than the pure $\mathrm{HO}$ cows $(+16 \mathrm{~kg}$ vs. + $28 \mathrm{~kg}$ ) from the first to last 14-d period.

The Pearson correlation coefficients between BW and BCS within breed groups ranged from +0.47 to +0.60 and were significantly $(P<0.05)$ different from zero within all 3 breed groups. The correlation between

Table 4. Least squares means and standard errors of means for hip height (cm), BCS, and BW (kg) of cows during the first $150 \mathrm{~d}$ of first lactation for breed groups

\begin{tabular}{|c|c|c|c|c|c|c|}
\hline \multirow[b]{2}{*}{ Trait } & \multicolumn{2}{|c|}{$\begin{array}{l}\text { Pure Holstein } \\
\quad(\mathrm{n}=40)\end{array}$} & \multicolumn{2}{|c|}{$\begin{array}{c}\text { Montbéliarde } \times \text { Holstein } \\
(\mathrm{n}=33)\end{array}$} & \multicolumn{2}{|c|}{ 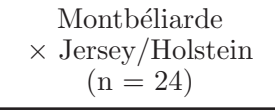 } \\
\hline & Mean & SEM & Mean & SEM & Mean & SEM \\
\hline Hip height $(\mathrm{cm})$ & 141.8 & 0.54 & 141.4 & 0.61 & $138.0^{* *}$ & 0.78 \\
\hline BCS & 2.74 & 0.03 & $3.32^{* *}$ & 0.04 & $3.29^{* *}$ & 0.05 \\
\hline BW (kg) & 528 & 6.2 & $564^{* *}$ & 7.1 & 537 & 8.9 \\
\hline
\end{tabular}

** $P<0.01$ for difference from pure Holstein cows. 
Table 5. Least squares means and standard errors of means for BW $(\mathrm{kg})$ of cows during the first $150 \mathrm{~d}$, in 14 -d intervals, of first lactation by breed group

\begin{tabular}{|c|c|c|c|c|c|}
\hline \multirow[b]{2}{*}{ 14-d period } & \multicolumn{2}{|c|}{$\begin{array}{l}\text { Pure Holstein } \\
\quad(\mathrm{n}=40)\end{array}$} & \multicolumn{2}{|c|}{$\begin{array}{l}\text { Montbéliarde-sired crossbreds } \\
\qquad(\mathrm{n}=57)\end{array}$} & \multirow[b]{2}{*}{ Difference } \\
\hline & Mean & SEM & Mean & SEM & \\
\hline 1 & 527 & 6.8 & 555 & 6.5 & $+28^{* *}$ \\
\hline 2 & 511 & 6.8 & 536 & 6.5 & $+25^{* *}$ \\
\hline 3 & 509 & 6.8 & 536 & 6.5 & $+27^{* *}$ \\
\hline 4 & 511 & 6.8 & 535 & 6.5 & $+24^{* *}$ \\
\hline 5 & 518 & 6.8 & 542 & 6.5 & $+24^{* *}$ \\
\hline 6 & 525 & 6.8 & 549 & 6.5 & $+24^{* *}$ \\
\hline 7 & 535 & 6.8 & 556 & 6.5 & $+21^{*}$ \\
\hline 8 & 540 & 6.8 & 561 & 6.5 & $+21^{*}$ \\
\hline 9 & 546 & 6.8 & 565 & 6.5 & $+19^{*}$ \\
\hline 10 & 555 & 6.9 & 571 & 6.6 & $+16 \dagger$ \\
\hline
\end{tabular}

** $P<0.01,{ }^{*} P<0.05, \dagger P<0.10$ for difference from pure Holstein cows.

BW and $\mathrm{HH}$ was significantly different from zero within the $\mathrm{MO} \times \mathrm{JH}$ crossbred cows $(+0.59)$ and pure HO cows $(+0.41)$; on the other hand, the correlation between $\mathrm{BW}$ and $\mathrm{HH}$ within the $\mathrm{MO} \times \mathrm{HO}$ crossbred cows $(+0.24)$ was not significantly different from zero. The correlation of BCS and $\mathrm{HH}$ was not significantly different from zero $(P>0.23)$ within any of the 3 breed groups.

Comparison of only $\mathrm{HH}, \mathrm{BCS}$, and BW does not provide a complete elucidation of the nutrient demands for depletion, accretion, or maintenance of adipose and muscle tissue; therefore, changes in body tissue composition of dairy cows during lactation warrant further study. More energy is required for adipose deposition compared with muscle tissue and water deposition (DiCostanzo et al., 1990); however, protein maintenance requires more energy than fat maintenance (Berry, 2009). Bewley and Schutz (2008) reviewed several studies that reported the DMI of cows is lower for cows carrying greater BCS, because body fat has a negative feedback effect on DMI.

Taylor et al. (1986) found differences in maintenance requirements for dairy and beef cattle with similar body composition, and De Campeneere et al. (2000) reported that dual-purpose breeds had greater change in muscle content as BCS changed, in contrast to pure HO cows, which primarily had changes in fat content. Perhaps MO-sired crossbred cows maintain BCS more efficiently than pure HO cows, because the MO breed was simultaneously selected over time for production, for higher BCS, and for feed conversion of progeny test bulls (Hansen, 2006) rather than against BCS as was done in the HO breed in the United States and Canada (Spahr and Opperman, 1995; Purebred Dairy Cattle Association, 2009). Apparently, the MO-sired crossbred cows in this study utilized energy in feed differently or mobilized body energy reserves differently than pure
HO cows, such that the MO-sired crossbred cows maintained greater BCS while producing equivalent fat plus protein production without consuming additional DMI.

Poor health status and reduced reproductive efficiency are the 2 primary reasons cows die or are culled (Pinedo et al., 2010), and replacement costs have a large effect on herd profitability (Evans et al., 2004; Heins et al., 2012). Incidences of health disorders were not available for the current study; however, MO-sired crossbred cows $(122 \mathrm{~d})$ had significantly fewer $(P<$ $0.05)$ days open (DO) during first lactation than did pure $\mathrm{HO}$ cows $(150 \mathrm{~d})$. If the cost per additional DO is approximated at $\$ 1.50$ (Cole et al., 2009b), the $28-\mathrm{d}$ fewer DO for the MO-sired crossbred cows provides them with a $\$ 42$ profit advantage over pure HO cows. Further research is warranted to compare the profitability of MO-sired crossbred cows and pure HO cows, and costs of health disorders should be included alongside other traits that are economically important for commercial dairies.

\section{CONCLUSIONS}

Because pure $\mathrm{HO}$ cows are predominant in the United States in the early 21st century, dairy producers are accustomed to managing cows with low to moderate BCS; therefore, dairy producers often assume that cows with higher BCS are consuming more DMI and, consequently, are less efficient producers of milk. Our results suggest that MO-sired crossbred cows, which had greater BCS than pure HO cows, were competitive with pure $\mathrm{HO}$ cows in converting the energy from DMI to fat plus protein production. The MO-sired crossbred cows had higher BCS and greater BW at calving, but their greater BCS and BW did not result in additional DMI compared with pure $\mathrm{HO}$ cows during the first 150 d of first lactation. Furthermore, the MO-sired cross- 
bred cows had a significant advantage of $28 \mathrm{~d}$ fewer DO. Potential advantages of MO-sired crossbred cows over pure $\mathrm{HO}$ cows for economic efficiency could result from heterosis, from simultaneous selection for production and BCS of cows and feed efficiency of bulls within the MO breed, or from a combination of both factors.

\section{ACKNOWLEDGMENTS}

The authors express gratitude to Bill Hansen and co-workers at the St. Paul (Minnesota) dairy facility for their assistance in data collection and care of animals. Supplemental funding for this project was provided by Coopex Montbéliarde (Roulans, France).

\section{REFERENCES}

Aharoni, Y., A. Brosh, and E. Kafchuk. 2006. The efficiency of utilization of metabolizable energy for milk production: A comparison of Holstein with $\mathrm{F}_{1}$ Montbeliarde $\times$ Holstein cows. Animal 82:101-109.

Auldist, M. J., M. F. S. Pyman, C. Grainger, and K. L. Macmillan. 2007. Comparative reproductive performance and early lactation productivity of Jersey $\times$ Holstein cows in predominantly Holstein herds in a pasture-based dairying system. J. Dairy Sci. 90:48564862.

Berry, D. P. 2009. Improving feed efficiency in cattle with residual feed intake. Pages 67-99 in Recent Advances in Animal Nutrition 2008. P. C. Garnsworthy and J. Wiseman, ed. Nottingham University Press, Nottingham, UK.

Bewley, J. M., and M. M. Schutz. 2008. Review: An interdisciplinary review of body condition scoring for dairy cattle. Prof. Anim. Sci. 24:507-529.

Buckley, F., B. Horan, N. Lopez-Villalobos, and P. Dillon. 2007. Milk production efficiency of varying dairy cow genotypes under grazing conditions. Pages 74-83 in Meeting the Challenges for PastureBased Dairying. Proc. Australasian Dairy Science Symposium, University of Melbourne, Australia.

Cole, J. B., D. J. Null, and P. M. VanRaden. 2009a. Best prediction of yields for long lactations. J. Dairy Sci. 92:1796-1810.

Cole, J. B., P. M. VanRaden, and Multi-State Project S-1040. 2009b. Net merit as a measure of lifetime profit: 2010 revision. Accessed Aug. 31, 2011. http://aipl.arsusda.gov/reference/nmcalc.htm.

De Campeneere, S., L. Fiems, and C. Boucqué. 2000. In vivo estimation of body composition in cattle. Nutr. Abstr. Rev. 70:495-508.

Dechow, C. D., G. W. Rogers, and J. S. Clay. 2001. Heritabilities and correlations among body condition scores, production traits, and reproductive performance. J. Dairy Sci. 84:266-275.

DiCostanzo, A., J. C. Meiske, S. D. Plegge, T. M. Peters, and R. D. Goodrich. 1990. Within-herd variation in energy utilization for maintenance and gain in beef cows. J. Anim. Sci. 68:2156-2165.

Dillon, P., F. Buckley, P. O'Connor, D. Hegarty, and M. Rath. 2003. A comparison of different dairy cow breeds on a seasonal grass-based system of milk production: 1. Milk production, live weight, body condition score and DM intake. Livest. Prod. Sci. 83:21-33.

Evans, R. D., P. Dillon, L. Shalloo, M. Wallace, and D. J. Garrick. 2004. An economic comparison of dual-purpose and Holstein-Friesian cow breeds in a seasonal grass-based system under different milk production scenarios. Irish J. Agric. Res. 43:1-16.

Ferguson, J. D., D. T. Galligan, and N. Thomsen. 1994. Principle descriptors of body condition score in Holstein cows. J. Dairy Sci. $77: 2695-2703$

Hansen, L. B. 2006. Monitoring the worldwide genetic supply for dairy cattle with emphasis on managing crossbreeding and inbreeding. CD-ROM Commun. no. 01-01 in Proc. 8th World Congress on Genetics Applied to Livestock Production, Belo Horizonte, Minas Gerais, Brazil. Instituto Prociencia, Belo Horizonte, Brazil.
Hansen, M., M. S. Lund, M. K. Sørensen, and L. G. Christensen. 2002. Genetic parameters of dairy character, protein yield, clinical mastitis, and other diseases in the Danish Holstein cattle. J. Dairy Sci. 85:445-452.

Heins, B. J., and L. B. Hansen. 2012. Short communication: Fertility, somatic cell score, and production of Normande $\times$ Holstein, Montbéliarde $\times$ Holstein, and Scandinavian Red $\times$ Holstein crossbreds versus pure Holsteins during their first 5 lactations. J. Dairy Sci 95:918-924

Heins, B. J., L. B. Hansen, and A. De Vries. 2012. Survival, lifetime production, and profitability of crossbreds of Holstein with Normande, Montbéliarde, and Scandinavian Red compared to pure Holstein cows. J. Dairy Sci. 95:1011-1021.

Heins, B. J., L. B. Hansen, A. J. Seykora, A. R. Hazel, D. G. Johnson, and J. G. Linn. 2008. Crossbreds of Jersey $\times$ Holstein compared with pure Holsteins for body weight, body condition score, dry matter intake, and feed efficiency during the first one hundred fifty days of first lactation. J. Dairy Sci. 91:3716-3722.

Heins, B. J., L. B. Hansen, A. J. Seykora, A. R. Hazel, D. G. Johnson, and J. G. Linn. 2011. Short communication: Jersey $\times$ Holstein crossbreds compared with pure Holsteins for production, mastitis, and body measurements during the first 3 lactations. J. Dairy Sci. 94:501-506.

Littell, R. C., P. R. Henry, and C. B. Ammerman. 1998. Statistical analysis of repeated measures data using SAS procedures. J. Anim. Sci. 76:1216-1231.

McAllister, A. J. 2002. Is crossbreeding the answer to questions of dairy breed utilization? J. Dairy Sci. 85:2352-2357.

McDowell, R. E. 1982. Crossbreeding as a system of mating for dairy production. Southern Coop. Series Bull. No. 259, Louisiana Agricultural Experiment Station, Baton Rouge.

NRC. 2001. Nutrient Requirements of Dairy Cattle. 7th rev. ed. Natl. Acad. Sci., Washington, DC.

O. S. Montbéliarde. 2012. Organisme de sélection de la race Montbéliarde. Accessed Apr. 20, 2012. http://www.Montbéliarde.org/ race-en.php.

Olson, K. M., B. G. Cassell, and M. D. Hanigan. 2010. Energy balance in first-lactation Holstein, Jersey, and reciprocal $\mathrm{F}_{1}$ crossbred cows in a planned crossbreeding experiment. J. Dairy Sci. 93:4374-4385

Pinedo, P. J., A. De Vries, and D. W. Webb. 2010. Dynamics of culling risk with disposal codes reported by dairy herd improvement dairy herds. J. Dairy Sci. 93:2250-2261.

Prendiville, R., K. M. Pierce, and F. Buckley. 2009. An evaluation of production efficiencies among lactating Holstein-Friesian, Jersey, and Jersey $\times$ Holstein-Friesian cows at pasture. J. Dairy Sci. 92:6176-6185

Pryce, J. E., M. P. Coffey, and G. Simm. 2001. The relationship between body condition score and reproductive performance. J. Dairy Sci. 84:1508-1515.

Purebred Dairy Cattle Association. 2009. Dairy cow unified scorecard. Accessed Aug. 31, 2011. http://www.purebreddairycattle.com/ file_open.php?id=2.

Rolfe, K. M., W. M. Snelling, M. K. Nielsen, H. C. Freetly, C. L. Ferrell, and T. G. Jenkins. 2011. Genetic and phenotypic parameter estimates for feed intake and other traits in growing beef cattle, and opportunities for selection. J. Anim. Sci. 89:3452-3459.

SAS Institute. 2008. SAS/STAT Software. Release 9.2. SAS Institute Inc., Cary, NC.

Schwager-Suter, R., C. Stricker, D. Erdin, and N. Künzi. 2001. Net energy efficiencies of Holstein, Jersey and Holstein-Jersey F1-crosses. Animal 72:335-342.

Shalloo, L., J. Kennedy, M. Wallace, M. Rath, and P. Dillon. 2004 The economic impact of cow genetic potential for milk production and concentrate supplementation level on the profitability of pasture based systems under different EU milk quota scenarios. J. Agric. Sci. 142:357-369.

Sørensen, M. K., E. Norberg, J. Pedersen, and L. G. Christensen. 2008. Invited review: Crossbreeding in dairy cattle: A Danish perspective. J. Dairy Sci. 91:4116-4128. 
Spahr, S. L., and G. E. Opperman. 1995. The Dairy Cow Today: US Trends, Breeding, and Progress Since 1980. Hoard's Dairyman, Fort Atkinson, WI.

Sutherland, T. M. 1965. The correlation between feed efficiency and rate of gain, a ratio and its denominator. Biometrics 21:739-749.

Taylor, St. C. S., R. B. Thiessen, and J. Murray. 1986. Inter-breed relationship of maintenance efficiency to milk yield in cattle. Anim. Prod. 43:37-61.

USDA-Agricultural Marketing Service. 2012. Federal Milk Marketing Order Statistics. Accessed Apr. 20, 2012. http://www.ams.usda. gov/AMSv1.0/DairyLandingPage.

USDA-National Agricultural Statistics Service. 2012. Milk Production, Disposition, and Income: 2011 Summary. Accessed July 30, 2012 http://usda01.library.cornell.edu/usda/current/MilkProdDi/Milk ProdDi-04-25-2012.pdf
VanRaden, P. M., and A. H. Sanders. 2003. Economic merit of crossbred and purebred US dairy cattle. J. Dairy Sci. 86:1036-1044

Walsh, S., F. Buckley, K. Pierce, N. Bryne, J. Patton, and P. Dillon. 2008. Effects of breed and feeding system on milk production, body weight, body condition score, reproductive performance, and postpartum ovarian function. J. Dairy Sci. 91:4401-4413.

Weigel, K. A., and K. A. Barlass. 2003. Results of a producer survey regarding crossbreeding on US dairy farms. J. Dairy Sci $86: 4148-4154$

Zwald, N. R., K. A. Weigel, Y. M. Chang, R. D. Welper, and J. S. Clay. 2004. Genetic selection for health traits using producerrecorded data. II. Genetic correlations, disease probabilities, and relationships with existing traits. J. Dairy Sci. 87:4295-4302. 